\title{
The state of estuarine knowledge of the communities of the Tyolomnqa Estuary in the Eastern Cape, South Africa
}

\author{
Pearl M. Maponya' and Patrick Ngulube ${ }^{2}$ \\ Information Studies Programme, School of Sociology and Social Studies, \\ University of KwaZulu-Natal, South Africa \\ maponyap@ukzn.ac.za,ngulubep@ukzn.ac.za
}

\begin{abstract}
Received: $2^{\text {nd }}$ June 2006
Accepted: $30^{\text {th }}$ August 2006

This article reports on a knowledge audit study that explored the state of estuarine knowledge sources, gaps and needs of the communities of the Tyolomnqa Estuary in the Eastern Cape from the perspectives of estuary users. Through a case study approach, unstructured and focus group interviews were conducted. The study found that the communities living along the Tyolomnqa Estuary did not have sufficient knowledge on how to address estuarine related problems. The findings revealed that lack of practical know-how, skills and expertise would result in irreplaceable natural resources like estuaries being threatened and destroyed. Enhancing estuarine knowledge may help the Tyolomnqa Estuary communities to act and make effective decisions about the sustainable management of the Estuary. However, for this to materialise there is a need to identify where knowledge is being created, where it already exists and where it is needed through a knowledge audit. Knowledge auditing is the first step in developing a knowledge management strategy.
\end{abstract}

Keywords: Estuaries, knowledge audit, knowledge management, knowledge transfer

\section{Introduction; setting the scene}

Estuary users who live along estuaries such as the Tyolomnqa need estuarine knowledge in order to effectively deal with the challenges related to protecting the estuarine environment. In other words, they need to apply the expertise that they have developed over time through being engaged in a number of activities linked to the management of estuaries. Some of the activities include biodiversity protection, sustainable use, rehabilitation, monitoring, and co-operative governance. At the same time, by being involved in various estuarine structures and forums, their skills and know-how may potentially be enhanced as they interact with other stakeholders within the field. Lack of that kind of engagement may result in the loss of natural resources such as estuaries. Initiatives that address these kinds of issues, supposedly through knowledge management have been proposed. In essence, knowledge auditing is the first step in developing a knowledge management strategy (Hylton 2002; Kelleher \& Levene 200 I; Liebowitz et al., 200 I; Sallis \& Jones 2002; Wiig 1995). A knowledge audit identifies where knowledge is being created, where it already exists and where it is needed to achieve knowledge management goals. It was in that light that the state of estuarine knowledge of the communities living along the Tyolomnqa Estuary in the Eastern Cape province of South Africa was investigated as a first step in understanding how existing knowledge may be managed for the effective and sustainable use of estuaries.

Estuarine management can be described as a knowledge-intensive activity which requires estuary users to maximise the understanding and use of their knowledge assets. Knowing how to do things better and being fit to respond to situations is crucial. In other words, knowledge provides and enhances the capacity to act. It is important that it is in the right context when needed. Considering that knowledge has become such an important asset, the future sustainability of estuarine resources will be directly related to the ability to identify, create, capture, acquire, share and disseminate estuarine knowledge by relevant actors and stakeholders. Thus, using the knowledge audit tool to identify the current state of estuarine knowledge, gaps and needs of communities living along estuaries is important.

Following this introduction, we shall provide a theoretical background by firstly giving a basic understanding of perhaps one of the most nebulous and difficult concepts - knowledge; and secondly, discussing the role of knowledge in the sustainable management of estuaries with specific reference to the Tyolomnqa Estuary in the Eastern Cape. In addition to that, we shall present and discuss the case study results.

\section{Knowledge and its dimensions}

Knowledge is a very complex and an intrinsically ambiguous term, and therefore defining it precisely is difficult (Okunoye 2003; Styhre 2003; Wiig 1993). However, one needs to understand that the nature of knowledge varies from discipline to

I. Pearl M. Maponya is lecturer in the Information Studies Programme, School of Sociology and Social Studies at the University of KwaZulu-Natal, South Africa

2. Patrick Ngulube (PhD) is associate professor in the Information Studies Programme, School of Sociology and Social Studies at the University of KwaZulu-Natal, South Africa

SA Jnl Libs \& Info Sci 2007, 73(I) 
discipline, for example, sociology, philosophy, economics, information science and recently knowledge management. In understanding the meaning of knowledge, many writers have addressed the distinctions between data, information, knowledge and wisdom (Allee 1997; Barquin 2000; Beller 200I; Bellinger, Castro and Mills 1997). On the other hand, Nonaka and Takeuchi (1995) distinguished between tacit and explicit knowledge. It is not our intention to enter into discussions and debates about these distinctions because the literature abounds with examples of these debates.

However, for the purpose of this discussion, knowledge is defined as 'a set of truths and beliefs, perspectives and concepts, judgments and expectations, methodologies and know-how'. It is a condition of knowing something gained through experience, observation and engagement with the environment. Liebowitz (2005:4) emphasized that 'knowledge must have context if it is to be useful to an organisation'. Thus, knowledge can be used and applied to handle contextspecific situations and problems. Knowledge enables individuals to perform and make decisions. Furthermore, it contributes to a large extent to the way individuals and organisations operate. In that regard, in order to understand how communities living along the Tyolomnqa Estuary effectively deal with the complex problems that they face, we need to be concerned with the state of their estuarine knowledge.

\section{The role of knowledge in the sustainable management of estuaries in the Eastern Cape}

Estuaries and the lands surrounding them are places of transition - where water from the land meets and mixes with the open sea (Department for Environment and Heritage 2005). In other words, estuaries are places where rivers meet the sea. Estuaries are well known for their high productivity, high carrying capacity and ability to support, apart from the resident species, a variety of migratory fish, birds and invertebrates (Whitfield 1992). They are valued for their scenic beauty and they are a source of recreation, education and aesthetic value. Estuaries are irreplaceable natural resources; protecting and managing them is therefore essential if the natural resources provided by estuaries and the quality of life offered by them is to be maintained (Harrison, Cooper and Ramm 2000; New South Wales, Department of Land and Conservation 2000).

The coastline of South Africa has a wide variety of estuaries, both on the eastern seaboard and the arid west coast. The estuaries of the Eastern Cape are on the eastern seaboard. They include the Fish, Kowie, Mngazana, Keiskamma Kasuka and Tyolomnqa estuaries. The Tyolomnqa Estuary, used as a case study, is situated approximately 45 kilometres west of East London, near the coastal resort of Kaisers Beach. It is attractive and its natural heritage has been maintained through a low level of physical development and recreational use. Subsistence farming takes place in the catchments and along the entire length of the river. Recreational impacts, such as fishing and general boating activities, are minimal and mostly confined to people living along the banks of the estuary. However, the estuary has a history of intermittent poaching and commercial fishing by outsiders (Institute of Natural Resources 2000).

The Tyolomnqa Estuary's naturalistic and underdeveloped nature inspired the researchers to use it as a case study. Furthermore, it represents the stark legacy of South Africa's recent past. The eastern bank is lined with the luxurious holiday homes while the western bank is occupied by impoverished residents of the former Ciskei Bantustan. The east bank communities consist of private owners from the Chalumna Estates and Chalumna Conservancy, and the west bank, which is land owned by the State under the jurisdiction of Tribal Authorities, is predominantly occupied by the Phozi, Xhama, Sandile and Ncera communities.

The estuarine environment is a very dynamic and complex environment, which poses threats and challenges to estuary users. Morant and Quinn, cited by the Institute of Natural Resources (200I), pointed out that the management of South African estuaries has been, on a piecemeal basis, driven by sectoral interests of various role players such as researchers, policy makers and the communities living along the Estuary. Lack of integrated planning and management to a large degree was regarded as a contributory factor to the fragmented approach to estuary management.

In that regard, researchers in the Eastern Cape Estuaries Management Programme (ECEMP), engaged in a collaborative effort to promote the formulation of management policies and procedures and to establish management structures for Eastern Cape estuaries. The ECEMP had four sub-programmes, namely the Local Estuary Management Sub-programme, the Estuary Management Institutional and Policy Development Sub-programme, the Estuary Management Capacity Building Sub-programme and the Estuary Management Research Sub-programme (Institute of Natural Resources 2001).

The complexity and diversity of a range of environmental, socio-economic, management and scientific issues and problems that are considered to be affecting the estuarine environment led the researchers within the Estuary Management Research Sub-programme, to search for innovative ways to manage and sustain the Eastern Cape estuaries through effective co-operative governance, co-operative management systems, sustainable use, biodiversity protection, rehabilitation, monitoring and knowledge management. 
As estuarine management is a very knowledge-intensive task, we as researchers within the knowledge management field conducted a study with communities living along the Tyolomnqa Estuary in the Eastern Cape Province of South Africa to explore the current state of estuarine knowledge, gaps and needs. In order to understand the state of knowledge of these communities, it was found imperative to conduct a knowledge audit.

Managing estuaries requires understanding and the use of practical knowledge. Lack of knowledge and skills to manage estuaries would result in natural resources like estuaries being threatened. Thus, to ensure continued success and effective management of estuaries, decisions should be based on sound scientific (and local) information and knowledge and with an agreed, attainable objective for the future state of the estuary. For local estuary users to have a better understanding of estuaries and their management, they need access to information and knowledge in order to participate actively in the whole process. Often estuary users find themselves faced with a challenge to effectively protect the estuarine biodiversity, sustain estuary resources, monitor, and rehabilitate the estuary resources with insufficient knowhow and expertise.

Information and knowledge play a fundamental role in the management of estuaries. Nath (2000) pointed out that:

Knowledge is empowering. Lack of knowledge is debilitating. Knowledge enables an individual to think, to analyse and to understand the existing situation, and the inter-linkages and externalities of each action ...

With knowledge, communities can broaden decisions, the scope of their actions and solve problems previously beyond their capacity. The management of knowledge is of increasing importance for local estuary managers and users in dealing with estuarine management challenges. According to Abdullah et al.(2005),"people use their knowledge in making decisions as well as many other actions". It is important that it is recognized and valued. Recognising the importance of the knowledge possessed by the community regarding estuaries, would help several researchers to develop strategies to sustain the estuarine environment. At the same time there is a need to establish an effective way of transferring and disseminating estuarine knowledge and information to local communities.

\section{The need to recognise the value of local people's knowledge}

It has been explored that the recognition of knowledge as an important resource has become evident in organisations and that its management is a critical and necessary factor for decision-making and organisational survival (Henczel 2000; Martensson 2000; Radebe 200I; Schaefer, Cook and Barrett 2002). This means recognizing the value of individual experiences, understanding, know-how and expertise within a particular environment.

However, we do need to give clarity in terms of the 'type' of knowledge that we place value on. That is, do we only value the knowledge that has been tried and tested through the use of the scientific method or knowledge that has been acquired through firsthand practical experience within local settings? There have been a lot of debates around the issue of local knowledge and scientific knowledge. However, one could possibly argue that both scientific and local knowledge are important in terms of broadening the knowledge base needed for problem-solving and decision-making regarding the sustainable management of natural resources. For example, Yli-Pelkonen and Kohl (2005) studied the role of local ecological knowledge in sustainable urban planning in the Helsinki metropolitan area in Finland. Their study found that local ecological knowledge exists among local residents.

Special attention should also be given within the estuarine management sector in terms of understanding the role of local estuarine knowledge generated by communities living along estuaries in adopting and sharing practices for improved management of estuaries. It is important to create awareness among researchers within the field of estuarine management that, in their quest for solutions that could help address issues impacting estuaries; they also need to recognize the value of knowledge possessed by local communities with regard to the estuarine environment.

Estuary users do possess a wealth of knowledge that enhances their capacity to address problems that are considered to be affecting the estuarine environment. As a result it is important that it be audited and managed. The natural resource management sector needs effective information and knowledge management capabilities. Sound, sustainable estuarine management depends on an access to information and knowledge that is context-specific. The philosophy behind managing the knowledge that people have is to develop and implement appropriate strategies and values to enable participants within an organisation or community to create, share and apply knowledge to achieve their goals.

\section{Profiling the knowledge of communities using the knowledge audit tool}

Using the knowledge audit as a first step in developing a knowledge management strategy will ensure successful management of knowledge (Hylton 2002; Kelleher and Levene 200I; Liebowitz et al., 200I; Sallis and Jones 2002; Wiig 1995), and in particular, the estuarine management knowledge. According to Hylton (2002:1), the knowledge audit is the "all important first major phase or step of a knowledge management initiative, and is used to provide a sound investigation into the company or organisation's knowledge".

SA JnI Libs \& Info Sci 2007, 73(I) 
In other words, the knowledge audit allows the organization to determine the knowledge needs and gaps; how knowledge is created, acquired and used; how knowledge flows through the organization; and to determine the organisation's intellectual assets and their value (Hylton 2002; Probst, Raub and Romhardt 2000; Stevens 2000). In essence, the knowledge audit as a process assesses potential stores of knowledge and identifies areas for improvement and opportunities so that the organization can better leverage knowledge for the achievement of its goals. It should be noted that knowledge audit processes are critical and need to be context-specific. As a result, short-circuiting them may result in a less optimum outcome of the knowledge audit. For the purpose of this study, the knowledge audit tool was contextualized to the estuarine environment.

\section{Research methodology and data collection procedures}

A case study was used in the present study to gain an in-depth insight into the knowledge status of the communities of the Tyolomnqa Estuary regarding the management of estuaries. Patton (2002) emphasised that case studies are valuable in creating an understanding of particular people and situations in comprehensive ways. One of the benefits of using a case study according to Oshri, Pan and Newell (2005:13), is "its ability to deal with a variety of evidence, documents, questionnaires, interviews and observations". The case study chosen involved conducting a knowledge audit to identify estuarine knowledge existing within the Tyolomnqa Estuary communities (that is, identifying knowledge generators and carriers), knowledge sources that enhance the utilisation and management of the estuary, and to identify the knowledge gaps and needs.

Data collected in this study included unstructured interviews with 16 people who were purposively selected due to their involvement in estuarine management issues, and five focus groups discussions with estuary users from the Tyolomnqa Estuary Forum, Phozi, Ncera, Sandile and Xhama communities. In order analyse the Tyolomnqa Estuary area's current knowledge status or health the following questions guided the knowledge audit.

I.What knowledge is needed in the Tyolomnqa Estuary area?

2.Who are the knowledge generators and carriers in the Tyolomnqa Estuary area?

3. What knowledge sources exist in the Tyolomnqa Estuary area?

4.What knowledge gaps exist in the Tyolomnqa Estuary area?

5.How can knowledge be used to enhance decision making in the Tyolomnqa Estuary area?

\section{Major research findings}

This sections deals with the major findings of the study. Each data collection procedure is discussed with the resultant findings.

\subsection{Unstructured interview findings}

Sixteen unstructured tape-recorded interviews were conducted with representatives from the Buffalo City Council, Chalumna Estates, Chalumna Conservancy, Tyolomnqa Estuary Forum, Phozi, Ncera, Sandile and Xhama communities. These representatives were key informants, with management positions and community leadership roles. This assisted in identifying the knowledge sources, gaps and needs of the estuary users in the Tyolomnqa Estuary area. Unstructured interviews provide enough freedom for respondents to steer the conversation, for example bringing in all sorts of tangential matters that have a bearing on estuarine management (Hakim 2000:35). The unstructured interviews were based on the knowledge and assumption that the participants possessed and in particular, information and knowledge about estuary management issues surrounding the Tyolomnqa area, on which they elaborated. Issues discussed are presented below.

\section{Participation in and knowledge of estuarine management issues}

Participants were asked to explain about their involvement in estuarine management issues in the Tyolomnqa Estuary area, as well as to share their experiences on how they learned about estuaries. The purpose of asking these questions was to predetermine the participants' know-how on issues surrounding the Tyolomnqa Estuary and their role in estuarine management issues.

It was found that most participants learned and acquired knowledge about estuaries through their participation in meetings and workshops, and their interaction with various actors within the field of estuarine management. Through their active involvement in estuarine issues, participants indicated that this had increased their interest in estuaries. Participants also indicated that they still need to learn more about estuaries and their management as they felt that the activities involved are very complex and challenging. Few participants said that they learned about estuaries at higher educational institutions. 


\section{Problems impacting on the Tyolomnqa Estuary}

Participants were asked about the major concerns and problems regarding the Tyolomnqa Estuary as well as what strategies did they employ in addressing them. These questions were trying to elicit whether the problems they encountered existed due to lack of integrated information and knowledge in sustaining the Tyolomnqa Estuary in terms of its status and resources. In addition to that, the questions were also trying to determine whether the participants had the necessary skills and know-how as well as if they know potential sources of information and knowledge. Problems identified were summarised as follows:

- Restricted public access to the Tyolomnqa Estuary.

- Lack of consensus among various government departments, local authorities and estuarine researchers regarding the state of management in terms of laws governing the estuaries, for example whether to allow limited access, free access or to regard the Tyolomnqa Estuary as a wilderness or protected area.

- Lack of infrastructure to enable the estuarine management structure to run properly.

- Over-utilisation and exploitation of Tyolomnqa Estuary resources, that is, subsistence fishing and bait collecting, intermittent poaching and commercial fishing from outsiders targeting the estuary.

- Lack of policing and law enforcement in the Tyolomnqa Estuary.

With regard to the problems that needed to be addressed, some participants indicated that they do not have sufficient information and knowledge in terms of how to address these issues. They indicated that the information that was at their disposal was too technical and needed simplistic guidelines. Those involved with the monitoring of the activities taking place at the Tyolomnqa Estuary pointed out that they do not know much about the enforcement of the laws and regulations governing the estuary. Some participants mentioned that when it came to addressing issues such as sedimentation, they have in most cases consulted experts from the Marine Working Group, Marine and Coastal Management and other estuarine experts from various government departments.

\subsection{Focus group interview findings}

Five focus group interviews were held with twelve respondents from the Tyolomnqa Estuary Forum, six from Phozi, ten from Ncera, eight from Sandile and twelve from Xhama. Greenbaum (1997) pointed out that that the selection of people in focus groups is based on their common characteristics relative to the issue being discussed. The selection of respondents in the focus groups was based on the role they play in issues that impact on the utilisation and management of the Tyolomnqa Estuary. Informants had a role to play when in issues such as governance, management systems, sustainable use, biodiversity protection, rehabilitation and monitoring as they related to the use of estuaries. In addition, focus groups discussions were held in order to elicit the knowledge that the communities possessed, used and required to manage estuaries. The focus group were composed of six to twelve participants as recommended in the literature. The findings are presented below.

\section{Reasons for taking part in estuarine issues}

The discussions were aimed at finding out the key interest of participants in estuaries. Participants gave various reasons for their involvement and participation in estuarine issues. Some participants from the Tyolomnqa Estuary Forum pointed out that they were keen to observe the Tyolomnqa Estuary and its natural beauty, because they think the estuary may attract tourists in the future. Most participants said their interest is focused on conservation issues and maintaining the ecology of the estuary. Some representative statements from the focus group transcripts in this regard are presented in Table I below.

Table I Participants' key interest in estuaries

\begin{tabular}{l} 
Participant I \\
I live on the banks of the Tyolomnqa Estuary; hence I am an interested and affected person in the future of the Estuary. I love the high \\
quality of the natural environment and I am very interested in all aspects of maintaining and improving the greater environment, that is, \\
the environment of the birds and of the fish and the social environment as well. \\
\hline Participant 2 \\
I became involved with the Tyolomnqa Estuary through my fishing activities ... I am keen to see the river remain in its natural state and \\
not be polluted or over-fished. \\
\hline Participant 3 \\
I have a key interest in ecology and I think this led to my involvement in the Tyolomnqa River, in order to be part of those who could help \\
maintain the quality of the river in all its aspects; make sure the river is there for enjoyment by the public under controlled \\
circumstances; and using this natural resource to create wealth, particularly in terms of job creation.
\end{tabular}


It is evident that participants have various reasons for engaging in estuarine issues. What they emphasised was that they needed to gain knowledge and experience that would help them in the optimum utilisation of the Tyolomnqa Estuary and its natural resources.

\section{Issues affecting estuary managers and users of the Tyolomnqa Estuary}

Participants were asked to discuss issues and problems that they are experiencing in the Tyolomnqa Estuary area. The discussions were trying to elicit whether participants had the necessary information and know-how on protecting and monitoring the estuary. The following were considered to be the major issues affecting the estuary managers and users:

- Lack of knowledge of how the community can create wealth for themselves from the Estuary, that is, how they can benefit from its resources.

- Lack of basic information and knowledge of how to address estuarine problems and conserve the natural resources.

- Lack of communication infrastructures in terms of arranging estuarine meetings.

- Lack of knowledge in terms of the laws and regulations governing the estuary.

- Lack of consensus among the community on the management of the estuary.

Approaches taken to address the issues

Participants were asked about what measures did they undertake to address these problems. The purpose of asking this question was to find out ways in which the estuary managers and users within the Tyolomnqa Estuary address challenging problems, in terms of knowing potential stores or sources of information and knowledge as well as determining the existing gaps within their own local knowledge base. In other words, do they know who to contact and where to go to if they have a specific problem that is beyond their frame of reference?

Participants indicated that they do not have specific knowledge pointers that would direct them to relevant sources of information and knowledge. In other words, they do not have relevant blueprints and toolkits to refer to. Some indicated that with the bylaws and guidelines that they have, they are too complicated and very difficult to understand. Participants identified that there is a knowledge gap when it comes to addressing some estuarine management issues. Thus, they suggested that it would be important if the local communities of the Tyolomnqa Estuary could be educated with issues such as conservation and sustainable use of resources. Participants stressed that the community should be educated continuously and that children at schools also be taught about estuaries.

\section{Discussion and analysis of research findings}

This section discusses what the collected data shows and determines the significance of results to the communities of the Tyolomnqa Estuary. Since this study is of a qualitative nature, content analysis was used to analyse the data both from unstructured and focus group interviews. The first step in content analysis entailed the construction of categories or themes that have been described by Sarantakos (1998:28I) as "a set of criteria which are integrated around a theme". In that light, data was analysed according to themes such as knowledge sources, knowledge identification, knowledge needs and gaps. These themes helped determine the knowledge health of the communities of the Tyolomnqa Estuary.

Knowledge identification and awareness of estuarine issues

It should be noted that in identifying the knowledge that the organisation has, it is important to examine how it is created, how it flows within as well as establishing how it adds value to the organisation (Probst, Raub and Romhardt 2000; Sallis and Jones 2002; Stevens 2000). The knowledge identification process aims at identifying that has been created, as well as knowledge that already exists but not yet identified.

With regard to the case of the Tyolomnqa Estuary, it was found that there was limited creation or generation of estuarine knowledge amongst loçal communities. However, the study established that the local estuary managers and users are aware of issues impacting on the estuary and that they have taken particular actions to address problems at hand. It is evident that the estuary managers and users lack relevant and sufficient information and knowledge needed to effectively protect, monitor and manage the estuary. It can be deduced that lack of knowledge can restrict one's choices (Duc 200 I). In addition, lack of knowledge affects the ability to make objective decisions, predict the effects of economic development and propose adequate responses. There is a need to build and enrich the local people's knowledge base on estuaries within the Tyolomnqa Estuary.

Potential knowledge sources

A very practical knowledge management activity is that of discovering knowledge sources within the organisation and mapping them (Fisher, Wandersee and Wideman 2000; Probst, Raub and Romhardt 2000). Knowledge sources are aimed at determining what and where knowledge exists within a particular community or organisation. These sources should include both tacit and explicit knowledge. In order to attain a useful understanding of the estuarine ecosystem, information and knowledge is needed. Few tacit knowledge sources such as experts from the Marine Working Group, 
Buffalo City Council, Marine and Coastal Management were at the disposal of the Tyolomnqa Estuary communities. With regard to explicit knowledge sources, the study established there is a lot of information (guidelines, blueprints, toolkits, etc) generated on estuaries but it is too technical and difficult for the local estuary managers and users to comprehend. In addition, most participants from in the areas of Phozi, Xhama, Ncera and Sandile do not know how and where to find information and knowledge pertaining to monitoring, protecting and rehabilitating the estuary. It is important for local communities to locate information and knowledge that is needed to address estuarine management issues and problems. Based on the findings, it becomes evident that there are insufficient knowledge sources for the communities of the Tyolomnqa Estuary. There is a need to repackage information and knowledge and establish knowledge pointers for the local communities.

Knowledge gaps and needs

One of the objectives of the knowledge audit is to identify what knowledge is missing in the targeted area and determine who needs it (Dataware Technologies, Inc. 1998; Kelleher and Levene 200I). The findings revealed that, regardless of the fact that the communities of the Tyolomnqa Estuary were aware of the issues impacting on the estuary, there was a huge knowledge gap. The knowledge gaps identified in the study lie in the following areas: practical management of estuaries, monitoring, laws and regulations governing estuaries, wealth creation and conservation and sustainability of estuarine resources. Due to lack of relevant knowledge, the local communities were unable to effectively address the problems and issues pertaining to estuaries such as sedimentation and dredging. This kind of knowledge gap can have a negative impact on the achievement of local estuarine management goals, which is the conservation and sustainability of estuarine resources.

\section{Conclusions and recommendations}

The complexity of the estuarine environment requires the use of practical knowledge and know-how to manage estuaries. The research found that the communities of the Tyolomnqa Estuary did not know where to find information pertaining to the conservation and preservation of the estuary. In other words, they do not know where to ask for expert advice. The knowledge created and generated in these communities, in terms of lessons learned and best practices, was not captured anywhere. However, it was found that there was limited creation or generation of estuarine knowledge amongst local communities. It was established that the Tyolomnqa Estuary communities had a substantial knowledge gap. Their knowledge gaps lied in the following areas: practical management of estuaries, monitoring, laws governing estuaries, wealth creation and conservation issues. It becomes evident that, even though there might be information and knowledge created in the Tyolomnqa Estuary, it is not easily available for the community to access. That means that there could be a lot of 'wheel-reinventing' that is going on in estuarine management.

Lack of knowledge and skills to address estuarine management issues and problems will have a negative impact. Knowledge plays a key role in the management of estuaries. Based on the findings, the study recommends that stakeholders such as research institutions, Institute of Natural Resources (INR), Water Research Commission (WRC) and Department of Environmental Affairs and Tourism (DEAT) should work in partnership to:

- Create and enrich local people's knowledge base. This will act as knowledge pointers in that they will enable the communities to access, use and apply the knowledge for the effective management of estuaries.

- Strengthen participation. Active participation and involvement on estuarine issues on various forums may help communities to learn, share information and knowledge amongst each other. In addition, the community should establish links with other estuary communities and experts. This will enhance learning and the acquisition of new knowledge to address particular issues. Participation can take the form of meetings, workshops, seminars, topic groups and informal gatherings.

- Need for continuous informal education. Awareness programmes should be established in schools and community centres about the nature of estuaries and how to protect them. Whitfield et al., (2000) pointed out that South African estuaries are threatened by many anthropogenic influences, such as lack of education, particularly among the public, local authorities and regional planners, with respect to the sustainable use of estuaries. Successful estuarine management requires clearly articulated practices that have public support. Much information and knowledge is created on estuaries but the problem is that it is not accessible. In other words, it is too technical and complicated. The challenge is to repackage it taking into consideration the literacy levels of local communities.

- Integrating 'scientific' and 'local' knowledge: bridging boundaries 


\section{Scientific Knowledge $\downarrow$}

Integrated Knowledge Base

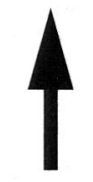

\section{Local People's Knowledge}

Figure 1 Integrating local and scientific

$$
\text { knowledge }
$$

Figure I illustrates that scientists (estuarine practitioners and researchers) can learn about estuarine management practices of local communities, and local communities (estuary managers and users) outside the scientific community can also learn the capabilities and limitations of estuarine management research. Bringing the two knowledges together may help both parties to address issues impacting on the natural resources sector.

This research tackled one estuary. There is a need for similar studies to be conducted in other estuaries of South Africa in order to compare the results of this study with other similar case studies. According to Rowley (2002:21), 'the more cases that can be marshalled to establish or refute a theory the more robust the research outcomes'. Further studies will also be necessary to develop mechanisms to implement the recommendations made by this study.

\section{References}

Abdullah, R., Selamat, M. H., Sahibudin, S. and Alias, R. A. 2005. A framework for knowledge management system implementation in collaborative environment for higher learning institution. Journal of Knowledge Management Practice. March. [Online]: http://www.tlainc.com/articl83.htm. Accessed 9 March 2006.

Allee, V. 1997. The knowledge evolution: expanding organizational intelligence. Boston: Butterworth-Heinemann.

Barquin, R. 2000. From bits and bytes to knowledge management. [Online]: http://www.barquin.com. Accessed 7 February 2006.

Beller, S. 200I. The DIKUW model, National Health Data Systems. [Online]: http://www.nhds.com/toc.htm. Accessed 5 January 2006.

Bellinger, G., Castro, D. and Mills, A. 1997. Data, information, knowledge and wisdom. [Online]: http://www.outsights.com/systems/ dikw/dikw.htm. Accessed 5 January 2006.

Dataware Technologies, Inc. 1998. Seven steps to implementing knowledge management in your organisation. Corporate executive briefing. [Online]: http://www.dataware.com. Accessed I2 February 2006.

Department for Environment and Heritage. 2004. Estuaries and the sea. [Online]: http://www.deh.gov.au/soe/soe96/ex-summary/ estuaries.html. Accessed 9 March 2006.

Department for Environment and Heritage. 2005. Estuaries management and planning. [Online]: http:// www.environment.sa.gov.au/coasts/estuaries.html. Accessed I November 2005.

Duc, Ho Ngoc, 200I. Resource-bounded reasoning about knowledge. [Online]: http://www.informatik.uni-leipzig.de/ duc/ Thesis/diss.html. Accessed 9 March 2006.

Fisher, K. M., Wandersee, J. H. and Wideman, G. 2000. Enhancing cognitive skills for meaningful understanding of domain specific knowledge. [Online]: http://www.sci.sdsu.edu/CRMSE. Accessed II February 2006.

Greenbaum, T. 1997. Using focus groups to add depth to your focus quality. [Online]: http://www.groupsplus.com/pages/quality.htm. Accessed 25 January 2006.

Hakim, C. 2000. Research design: successful design for social and economic research. $2^{\text {nd }}$ ed. London: Routledge.

Harrison, T. D., Cooper, J. A. G. and Ramm, A. E. L. 2000. Geomorphology, ichthyfauna, water quality and aesthetics of South African estuaries. Prepared by Division of Water, Environment and Forestry Technology. Prepared for the Department of Environmental Affairs and Tourism. [Online]: http://www.environment.gov.za/soer/reports/ehi/ehi_chl.pdf. Accessed I4 January 2006).

Henczel, S. 2000. The information audit as a first step towards effective knowledge management: an opportunity for the special librarian. INSPEL 34(3/4):210-226. [Online]: http://www.fh-postdam.de/ IFLA/INSPEL/00-3hesu.pdf. Accessed 28 February 2006.

Hylton, A. 2002. A knowledge audit must be people-centred and people focused. [Online]: http://www.knowledgeboard.com/library/ people_centred_knowledge_audit.pdf. Accessed 6 February 2006.

Institute of Natural Resources. 2000. Tyolomnqa Estuary: stakeholders workshop. [Online]: http://www.inr.unp.ac.za.ecestuaries/ management/tyolomnqa/StakeholderWSJue.htm. Accessed 5 January 2006.

Institute of Natural Resources. 2001. Eastern Cape Estuaries Management Research Sub-programme project progress. Pietermaritzburg: Institute of Natural Resources.

Kelleher, D. and Levene, S. 200I. Knowledge management: a guide to good practice. London: British Standards Institution.

Liebowitz, J., Rubenstein-Montano, B., McCaw, D., Buchwalter, J. and Browning, C. 200I. The knowledge audit. [Online]: http:// userpages.umbc.edu/ buchwalter/papers/Kmaudit.htm. Accessed 4 March 2006.

Liebowitz, J. 2005. Conceptualising and implementing knowledge management. In Love, P.E.D., Fong, P.S.W and Irani, Z. (eds). 2005. Management of knowledge in project environments. Amsterdam: Elsevier Butterworth-Heinemann. pp. I-I8.

Martensson, M. 2000. A critical review of knowledge management as a management tool. Journal of Knowledge Management 4(3):204-2 16. [Online]: http://pinkerton.emeraldinsight.com. Accessed 06 January 2006).

Nath, V. 2000. Heralding ICT enabled knowledge societies: the way forward for the developing countries. [Online]: http:// 216.197.119.1/3/vikas/heralding.htm. Accessed 9 March 2006. 
New South Wales, Department of Land and Water Conservation. 2000. About estuaries: major issues. [Online]: http:// wwwdlwc.nsw.gov.au/care/water/estuaries/About/issues.html. Accessed 20 January 2006.

Newell, S., Robertson, M., Scarbrough, H. and Swan, J. 2002. Managing knowledge work. Basingstoke, Hampshire: Palgrave.

Nonaka, I. and Takeuchi, H. 1995. The knowledge-creating company: how Japanese companies create the dynamics of innovation. Oxford: Oxford University Press.

Okunoye, A. O. 2003. Knowledge management and global diversity: a framework to support organisations in developing countries. PhD thesis. Turku: University of Turku. [Online]: http://www.tucs.fi/publications/attachment.php?fname=DISS46.pdf. Accessed 9 March 2006.

Oshri, I., Pan, S. L. and Newell, S. 2005. Trade-offs between knowledge exploitation and exploration activities. Knowledge Management, Research and Practice 3(I): 10-23.

Patton, M.Q. 2002. Qualitative research and evaluation methods. Thousand Oaks: Sage.

Radebe, T. 200I. Challenges facing librarians and information workers in the knowledge age. Paper presented at LIASA Conference on African Renaissance through libraries, Johannesburg, South Africa. 24-28 September 2001.

Rowley, J. 2002. Using case studies in research. Managing Research News 25(I): 16-27.

Sallis, E. and Jones, G. 2002. Knowledge management in education. London: Kogan Page.

Sarantakos, S. 1998. Social research. 2nd ed. London: Macmillan Press Ltd.

Schaefer, M., Cook, J. S and Barrett, J. 2002. Creating competitive advantage in large organisations using knowledge management. Decision Sciences Institute 2002 Annual Meeting Proceedings. [Online]: http://www.sbaer.uca.edu/Research/2002/dsi/Papers/ 213.pdf. Accessed 17 February 2006.

Skyrme, D. 2002. Knowledge management: approaches and policies. [Online]: http://www.skyrme.com/pubs/deeds_km.doc. Accessed 7 January 2006.

Stevens, L. 2000. Knowing what your company knows. Knowledge Management Magazine: 38-42. [Online]: http:// www.destinationcrm.com/km/dcrm_km_article.asp?id=475. Accessed 28 February 2006.

Styhre, A. 2003. Understanding knowledge management: critical and post-modern perspectives. Herndon, Va: Copenhagen Business School Press.

Ubogu, F. N. 200I. Knowledge management for decision-making: tools, institutions and paradigms. Paper presented at the $2^{\text {nd }}$ meeting of the Committee on Development Information of the United Nations Economic Commission for Africa, Addis Ababa, Ethiopia. 4-7 September 2001.

Wiig, K.M. 1993. Knowledge management foundations: thinking about thinking: how people and organisations create, represent and use knowledge. Arlington, TX: Schema Press.

Whitfield, D. 1992. South African estuaries. [Online]: http://www.upe.ac.za/cerm/cerm2.html. Accessed 9 November 2002.

Whitfield, A. K., Taylor, R. H., Grange, N., Cowley, P. D., Wooldridge, T. H., Adams, J. B. and Bate, G. C. 2000. Functional ecosystems: estuaries. [Online]: http://www.nrf.ac.za/publications/marinerep/estuaries.htm. Accessed I5 February 2006).

Wiig, K. M. 1995. Knowledge management methods: practical approaches to managing knowledge. Arlington, TX: Schema Press.

Yli-Pelkonen, V. and Kohl, J. 2005. The role of local ecological knowledge in sustainable urban planning: perspectives from Finland. Sustainability: Science, Practice and Policy I(I):3-I4. 